\title{
Estimation of Deflections in Cantilever and Fixed Castellated Beams with Hexagonal, Square and Circular Openings
}

\author{
Atteshamuddin S. Sayyad ${ }^{1 *}$, Ajim S. Shaikh ${ }^{2}$ \\ ${ }^{1}$ Department of Civil Engineering, SRES's Sanjivani College of Engineering, Savitribai Phule Pune University, Kopergaon- \\ 423601, Maharashtra, India \\ ${ }^{2}$ Department of Civil Engineering, AJMVPS's Shri Chatrapati Shivaji Maharaj College of Engineering, Savitribai Phule Pune \\ University, Nepti-414005, Ahmednagar, Maharashtra, India \\ Corresponding Author Email: attu_sayyad@yahoo.co.in
}

https://doi.org/10.18280/ti-ijes.640118

Received: 10 May 2019

Accepted: 7 January 2020

\section{Keywords:}

castellated beams, experimental investigation, cantilever beam, fixed beam, torsional buckling, bending

\begin{abstract}
The majority of existing literature on castellated beams focuses on simply supported boundary conditions. But studies on cantilever and fixed boundary condition are limited in the literature. Therefore the present study provides a new experimental solution for bending of cantilever and fixed castellated beams. The experimental investigation on castellated beams with hexagonal, circular and square openings is carried out for cantilever and fixed end conditions and compared with normal beam without opening. All the beams are tested under universal testing machine and subjected to central point load. Experimental results are obtained for maximum deflections and transverse load carrying capacity and validated numerically by using finite element method. ANSYS 14.0 version is used for the finite element analysis. Finally, it is concluded that the present study will serve as a benchmark study for cantilever and fixed castellated beams.
\end{abstract}

\section{INTRODUCTION}

A solid web steel beam with perforation (openings) is called as a castellated beam (CB). Use of CB for various structures is increasing rapidly due to its advanced structural properties and easy construction. Also in CB, depth of the section is increased without any addition of weight, which ultimately increases moment of inertia and the load carrying capacity. The CB has less shear capacity due to effect of stress concentration at the web openings. Therefore, it is recommended to provide openings/perforations closer to neutral axis where the stresses are almost zero. Chung et al. [1] and Liu and Chung [2] presented Vierendeel mechanism in steel beams with web openings based on analytical and numerical approaches. Zirakian and Showkati [3] and Zirakian [4] performed an experimental investigation on simply supported CB subjected to central concentrated load. Many researchers have presented finite element analysis on castellated beams with and without openings such as Mohebkhah [5], Mohebkhah and Showkati [6], Wang and Chung [7], El-Sawy et al. [8], Gholizadeh et al. [9], Sweedan [10], Ellobody [11], Wakchaure and Sagade [12], Soltani et al. [13], Wong and Burgess [14], Erdal and Saka [15], Jamadar and Kumbhar [16], Wang et al. [17], Elsawaf and Hassan [18], Tsavdaridis and Papadopoulos [19], Zhou et al. [20] etc.

Harte and Baylor [21] and, Baylor and Harte [22] presented the structural behaviour of timber joists with hexagonal openings in its webs. Gandomi et al. [23] used Gene expression programming to develop a model to predict the load capacity of castellated steel beams. Erdal et al. [24] developed the design techniques to optimize solutions of three different types of beams. Durif and Bouchair [25] studied CBs with sinusoidal openings by both experimentally as well as numerically. Tsavdaridis and D'Mello [26] investigated buckling behaviour of the web in CBs with innovative shapes of opening. Showkati et al. [27] have tested simply supported CBs subjected to pure bending. Durif et al. [28] investigated behaviour of CBs with sinusoidal openings and compared with circular openings. There are some other studies available in the literature on bending and buckling behaviour of castellated beams such as Abidin and Izzuddin [29], Yuan et al. [30], Sonck et al. [31], Sorkhabi et al. [32], Wang et al. [33, 34], Ellobody and Young [35], Tsavdaridis et al. [36], Sonck and Belis [37, 38], Wang et al. [39], Najafi and Wang [40], Grilo et al. [41], Zaher et al. [42] etc.

In the present study, three groups of castellated steel beam are analyzed to show the effect of opening shape on the web post buckling behavior. The experimental investigation on castellated beams with hexagon, circle and square shapes of openings is carried out for cantilever and fixed end conditions and compared with normal beam without opening. Both the beams are tested under universal testing machine and subjected to central point load. Experimental results are obtained for critical buckling loads and validated numerically by using finite element method. ANSYS 14.0 version is used for the finite element analysis. Finally, it is concluded that the present study will serve as a benchmark study for cantilever and fixed castellated beams.

\section{CASTELLATED BEAMS UNDER CONSIDERATION}

Web post, castellation, throat width, throat depth, top and bottom tee etc. are the important terminologies used in the 


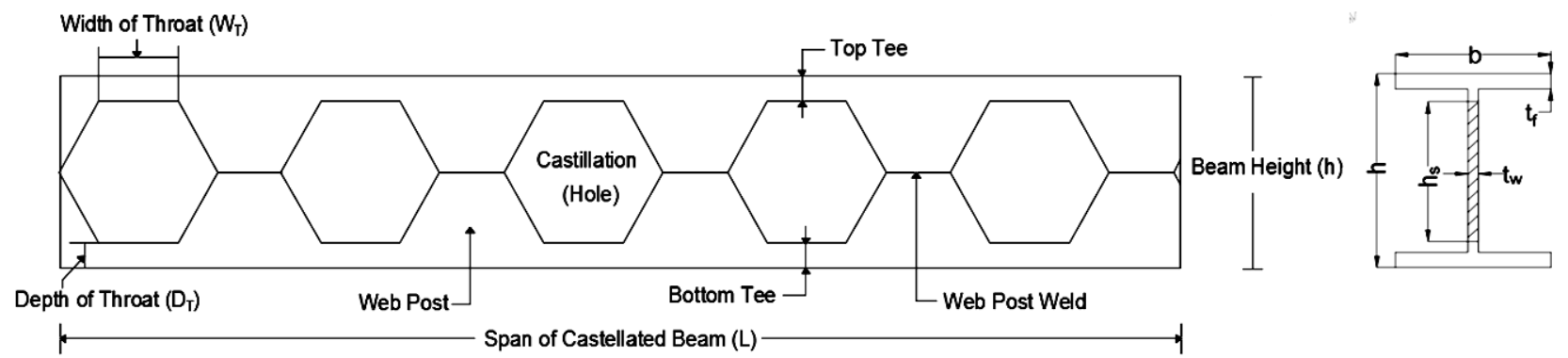

Figure 1. Terminologies of castellated beam with hexagonal opening

\subsection{Fabrication of castellated beam under consideration}

In the present study castellated beams are fabricated in following steps also shown in Figure 2.

Step 1: Firstly, 12 pieces of I-section having length $1 \mathrm{~m}$ each are taken. Three shapes of web opening are chosen (hexagonal, square, circular). Hence, 3 pieces are used for each opening and 3 pieces are used for normal beam without opening.

Step 2: Then the cutting alignments are marked to each of the three pieces of hexagonal, square, circular openings.

Step 3: Then by using a gas cutter, all nine I-sections are cut in pre-determined cutting alignments.

Step 4: Two separated parts in step 3 are then welded faceto-face to get the castellated beams of required opening shapes.

Step 5: Finally, the un-aligned parts are filled by welding plates at the corner to make the stability.

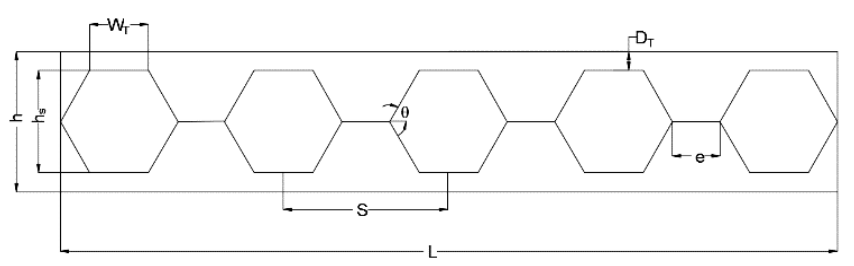

Figure 2. Design of castellated beams with hexagonal opening

\subsection{Design of castellated beams}

In the present study, three types of castellated beams are considered to provide a new experimental solution for bending analysis of cantilever and fixed boundary conditions.

\subsubsection{Hexagonal opening}

Figure 3 shows castellated beam with hexagonal opening. The angle of cut is selected to be in between $45^{\circ}$ to $65^{\circ}$. Following are the parameters considered for this beam in the present study.

1. Overall Height $(h)-175 \mathrm{~mm}$

2. Height of perforation $\left(h_{\mathrm{s}}\right)-112 \mathrm{~mm}$

3. Total span of beam $(L)-1130 \mathrm{~mm}$

4. Width of throat $\left(W_{\mathrm{T}}\right)-90 \mathrm{~mm}$

5. Spacing between two perforation $(S)-264 \mathrm{~mm}$

6. Angle of cut $(\theta)-55^{\circ}$

7. Depth of throat $\left(D_{\mathrm{T}}\right)-31.5 \mathrm{~mm}$

8. Distance between two perforation (e) - $65 \mathrm{~mm}$
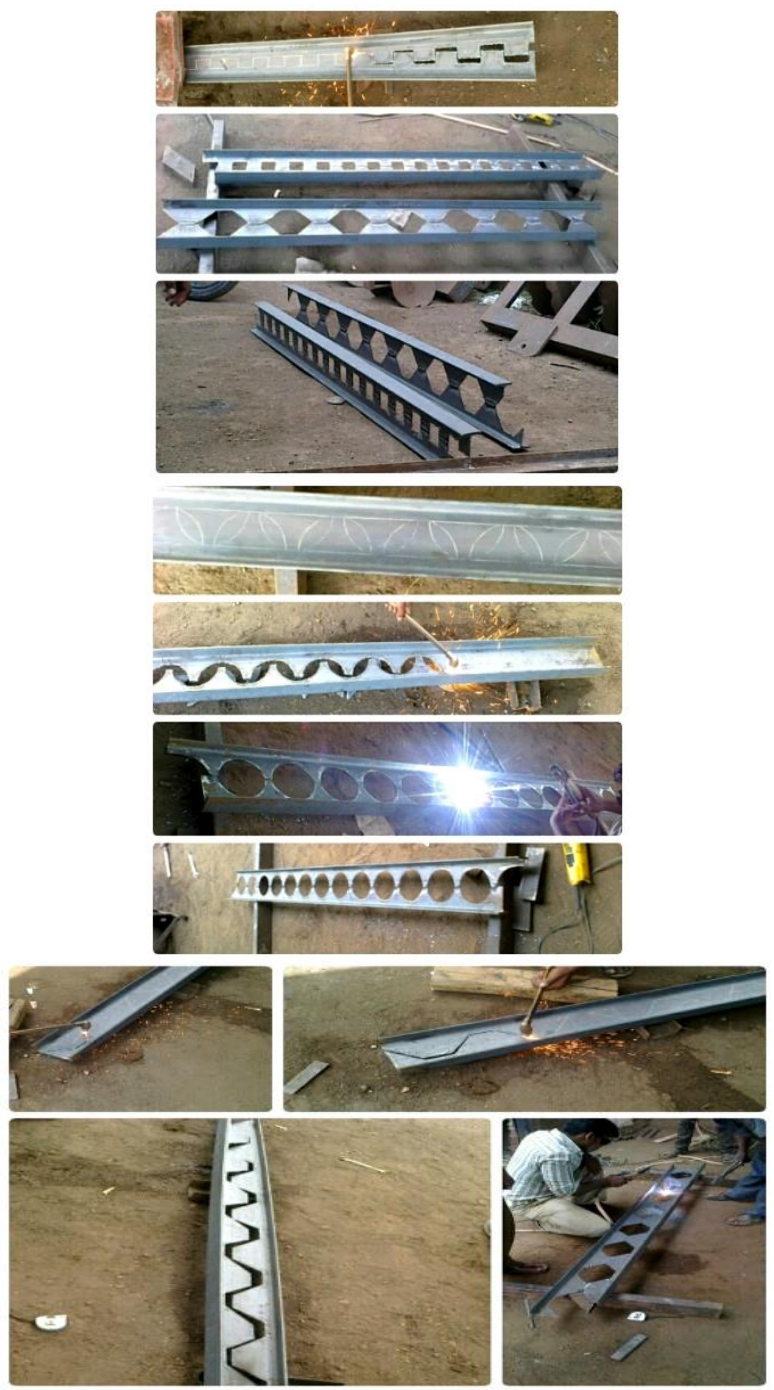

Figure 3. Fabrication of castellated beams

\subsubsection{Square opening}

Figure 4 shows castellated beam with square opening. Following are the parameters considered for this beam in the present study.

1. Overall Height $(h)-153 \mathrm{~mm}$

2. Height of perforation $\left(h_{\mathrm{s}}\right)-60 \mathrm{~mm}$

3. Total span of beam $(L)-1100 \mathrm{~mm}$

4. Width of throat $\left(W_{\mathrm{T}}\right)-60 \mathrm{~mm}$

5. Spacing between two perforation $(S)-120 \mathrm{~mm}$

6. Depth of throat $\left(D_{\mathrm{T}}\right)-46.5 \mathrm{~mm}$

7. Distance between two perforation $(e)-60 \mathrm{~mm}$ 


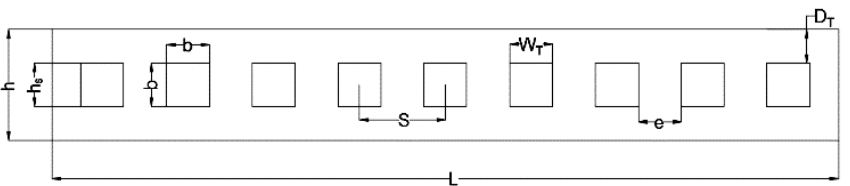

Figure 4. Design of castellated beams with square opening

\subsubsection{Circular opening}

Figure 5 shows castellated beam with circular opening. Following are the parameters considered for this beam in the present study.

1. Overall Height $(h)-180 \mathrm{~mm}$

2. Height of perforation $\left(h_{\mathrm{s}}\right)-120 \mathrm{~mm}$

3. Total span of beam $(L)-1100 \mathrm{~mm}$

4. Width of throat $\left(W_{\mathrm{T}}\right)-120 \mathrm{~mm}$

5. Spacing Between two perforation $(S)-152 \mathrm{~mm}$

6. Depth of throat $\left(D_{\mathrm{T}}\right)-30 \mathrm{~mm}$.

7. Diameter of perforation $(\phi)-120 \mathrm{~mm}$

8. Distance between two perforation (e)- $40 \mathrm{~mm}$

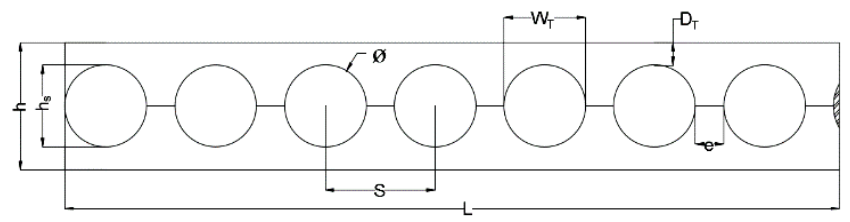

Figure 5. Design of castellated beams with circular opening

\section{FABRICATION OF FIXED SUPPORT ASSEMBLY}

In this study, an experimental solution for bending analysis of cantilever and fixed castellated beams is provided. Since in Universal Testing Machine (UTM) only tests on simply supported beams are possible, for the cantilever and fixed boundary conditions a new support assembly is developed by the authors. When this assembly is provided on both ends of the beams, the beam is called fixed beam whereas when only one end is supported by this assembly and other is free it is called as cantilever beam. Figure 6 shows assembly of fixed support. The procedure for preparing fixed support assembly is given below:
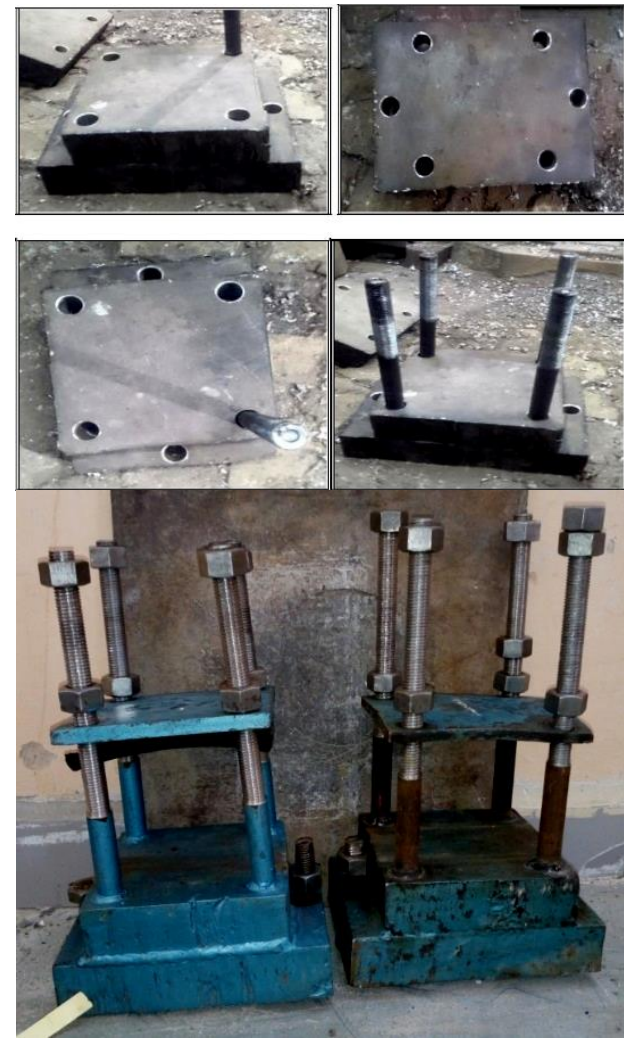

Figure 6. Fixed support testing assembly

Bottom plate is of size $165 \mathrm{~mm} \times 230 \mathrm{~mm}$. This bottom plate will be connected to movable cross head of a UTM. Castellated beam is resting on upper plate of size $165 \mathrm{~mm} x$ $170 \mathrm{~mm}$. Stud of diameter $16 \mathrm{~mm}$ is used. Stud is made up of steel material of type E81. Studs are provided at the four corners of the upper and bottom plates. Total length of the stud is $500 \mathrm{~mm}$ out of which $350 \mathrm{~mm}$ from top is threaded. Pass the steel plate through stud and tight it by using rubber pad and then lock the castellated I-Section by steel plates and rubber pad using four bolts.

\section{EXPERIMENTAL INVESTIGATION}

\subsection{Testing on castellated cantilever beams}

Table 1. Deflection at center and free end of the castellated cantilever beams without and with web openings

\begin{tabular}{|c|c|c|c|c|c|c|c|c|}
\hline \multirow{2}{*}{ Load (kN) } & \multicolumn{9}{|c|}{ Deflection (mm) } \\
\cline { 2 - 9 } & \multicolumn{2}{|c|}{ Normal beam } & Hexagonal opening & \multicolumn{2}{c|}{ Square opening } & \multicolumn{2}{c|}{ Circular opening } \\
\cline { 2 - 10 } & Center & Free end & Center & Free end & Center & Free end & Center & Free end \\
\hline 10 & 0.132 & 1.245 & 0.027 & 0.232 & 0.093 & 0.789 & 0.055 & 0.412 \\
\hline 20 & 0.265 & 2.490 & 0.053 & 0.465 & 0.169 & 1.435 & 0.109 & 0.824 \\
\hline 30 & 0.397 & 3.735 & 0.159 & 1.394 & 0.254 & 2.152 & 0.164 & 1.237 \\
\hline 40 & 0.530 & 4.979 & 0.212 & 1.859 & 0.339 & 2.869 & 0.219 & 1.649 \\
\hline 50 & 0.662 & 6.224 & 0.266 & 2.324 & 0.423 & 3.587 & 0.273 & 2.061 \\
\hline 60 & 0.795 & 7.469 & 0.319 & 2.788 & 0.508 & 4.304 & 0.328 & 2.473 \\
\hline 70 & 0.927 & 8.714 & 0.372 & 3.253 & 0.593 & 5.021 & 0.383 & 2.885 \\
\hline 80 & 1.059 & 9.959 & 0.425 & 3.718 & 0.677 & 5.739 & 0.437 & 3.298 \\
\hline 90 & 1.192 & 11.204 & 0.478 & 4.182 & 0.762 & 6.456 & 0.492 & 3.710 \\
\hline 100 & 1.324 & 12.448 & 0.531 & 4.647 & 0.847 & 7.173 & 0.547 & 4.122 \\
\hline 110 & 1.457 & 13.693 & --- & --- & 0.931 & 7.891 & 0.601 & 4.534 \\
\hline 120 & --- & --- & --- & - & 1.016 & 8.608 & 0.656 & 4.947 \\
\hline
\end{tabular}


Table 1 shows numerical values of deflection in cantilever normal and castellated beams subjected to central point load. Deflection is measured at two locations i.e. center and free end. Comparison of castellated beams with web opening is done with normal beam of I-section without opening. For experimental investigation, overall height of the normal beam is taken as $h=125 \mathrm{~mm}$ and length is taken as $L=1100 \mathrm{~mm}$. Examination of Table 1 reveals that the central as well as free end deflections are minimum in castellated beam with hexagonal opening whereas those are maximum in normal beam without opening. Deflections for CBs with hexagon and circular shape of openings are more or less same. Figure 7 shows bending of flange and buckling of web in normal Isection beam without opening subjected to central point load. Variation of deflection with respect to load in cantilever normal beam is shown in Figure 8. Figures 10-12 show bending of flange and buckling of web in castellated beams with hexagonal, square and circular openings whereas Figures 13-15 show variation of deflection with respect to load in castellated beams.
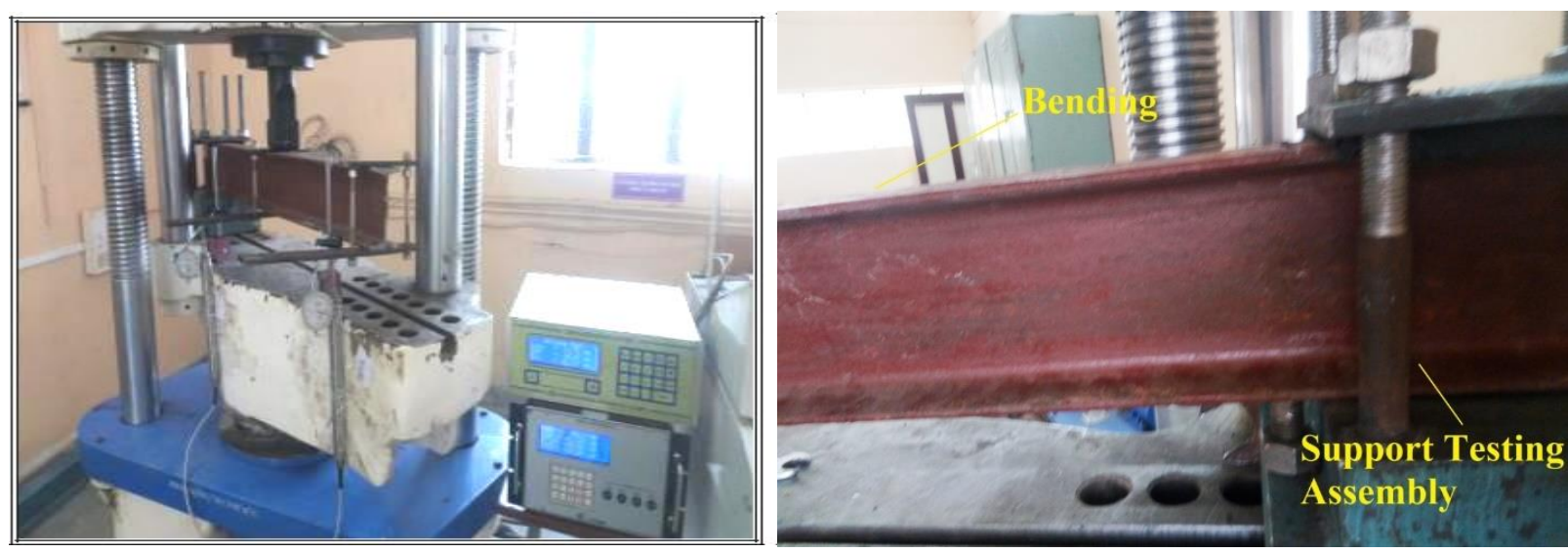

Figure 7. Lateral torsional buckling and bending of cantilever normal beam (without opening)
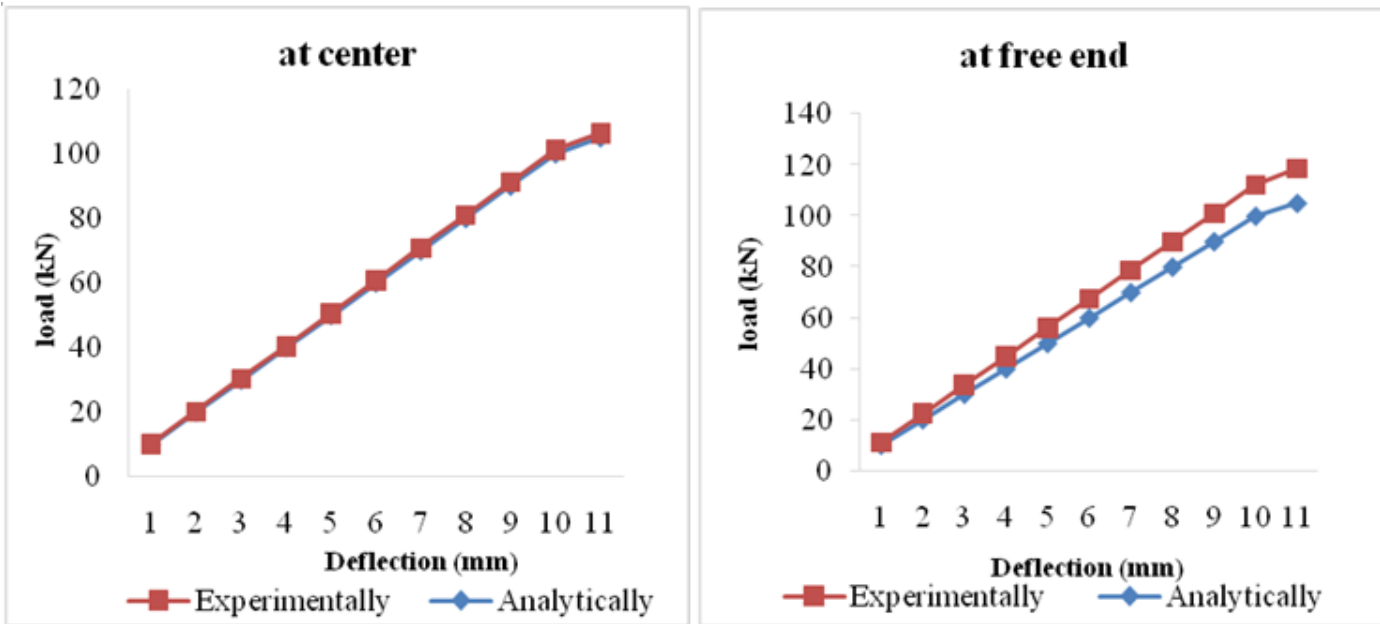

Figure 8. Load vs deflection curve in cantilever normal beam

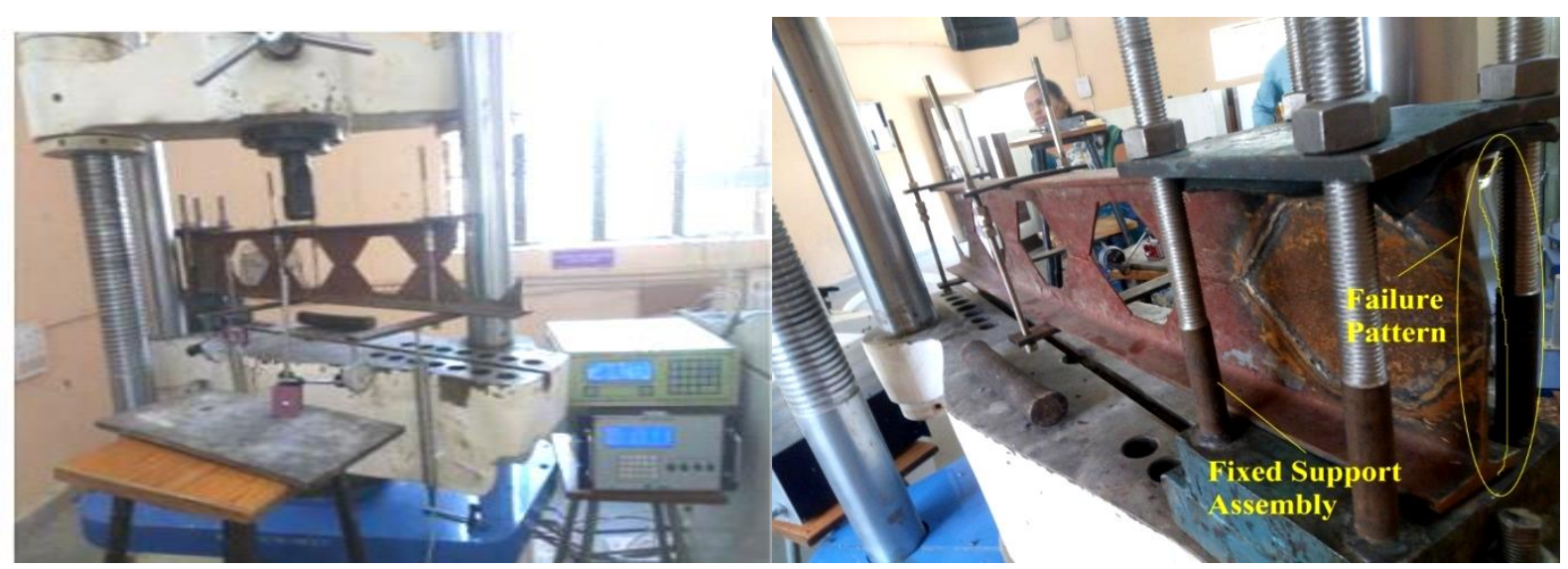

Figure 9. Lateral torsional buckling and bending in castellated cantilever beam with hexagonal opening 

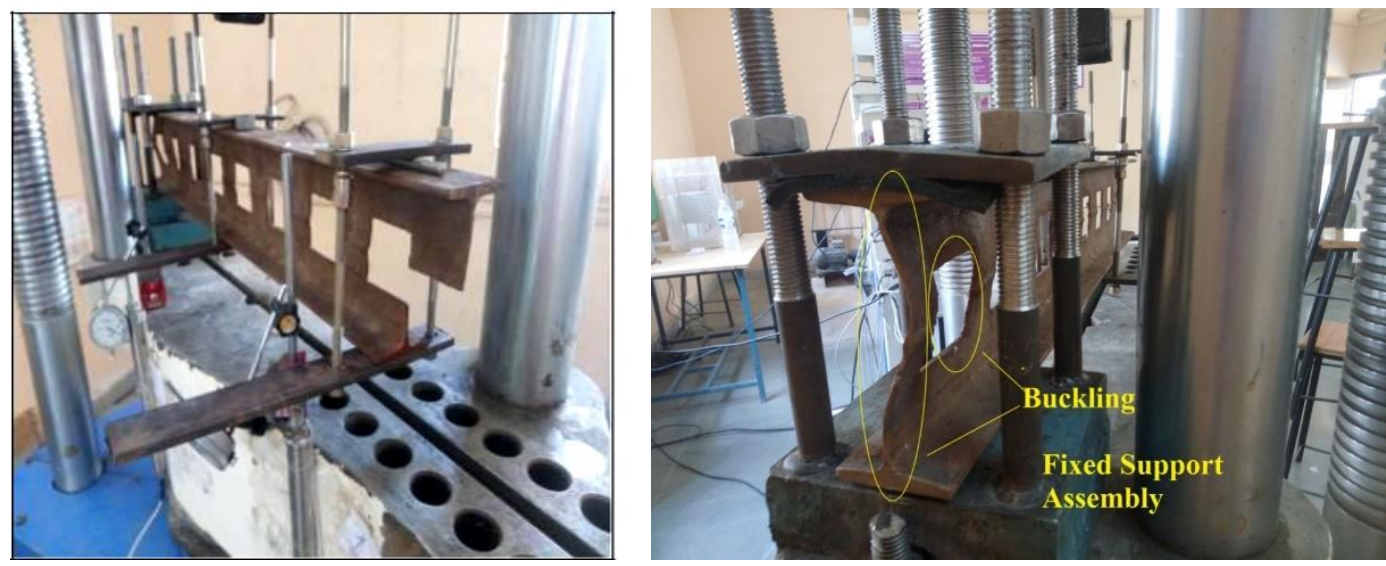

Figure 10. Lateral torsional buckling and bending in castellated cantilever beam with square opening
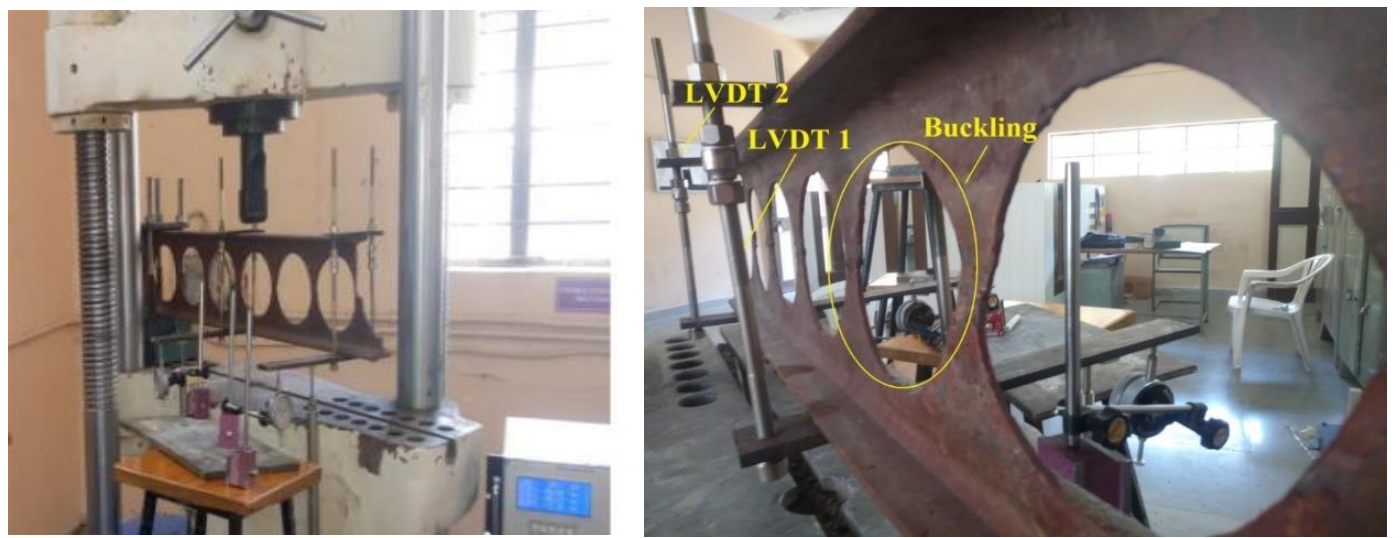

Figure 11. Lateral torsional buckling and bending in castellated cantilever beam with circular opening
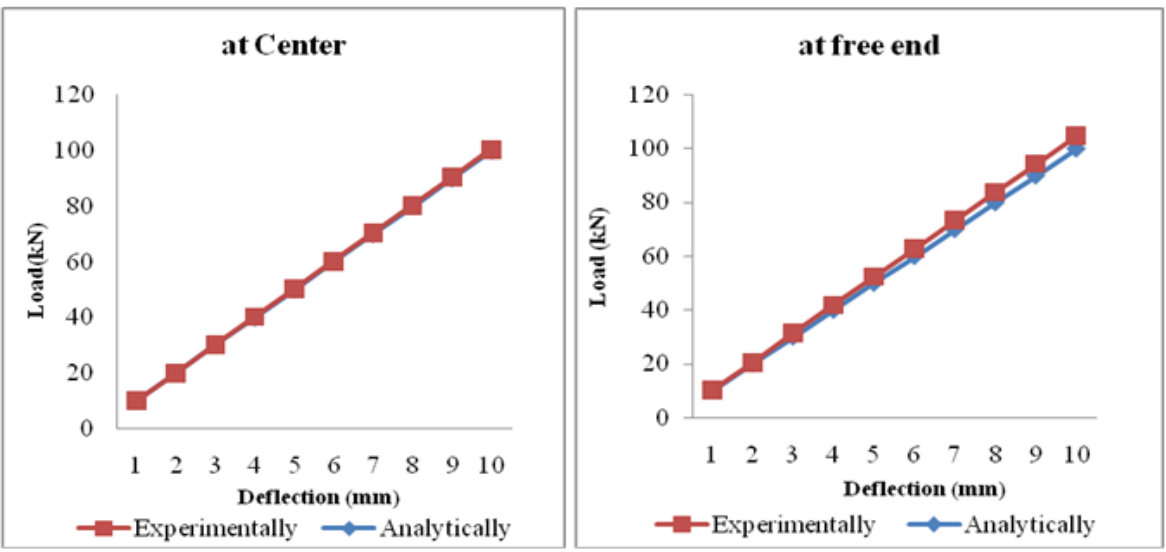

Figure 12. Load vs deflection curve in castellated cantilever beam with hexagonal opening
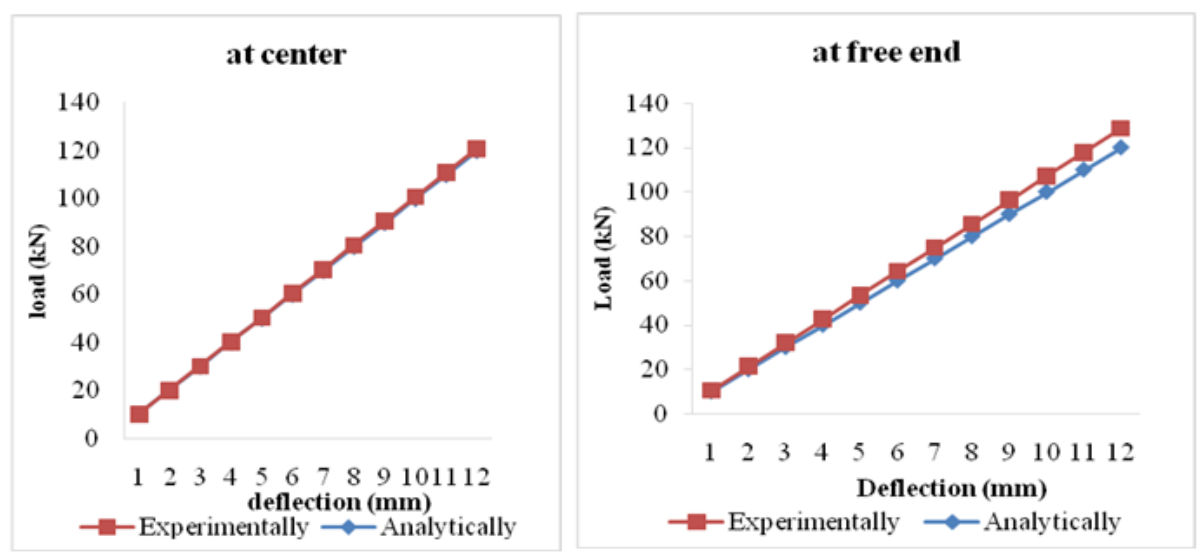

Figure 13. Load vs deflection curve in castellated cantilever beam with square opening 

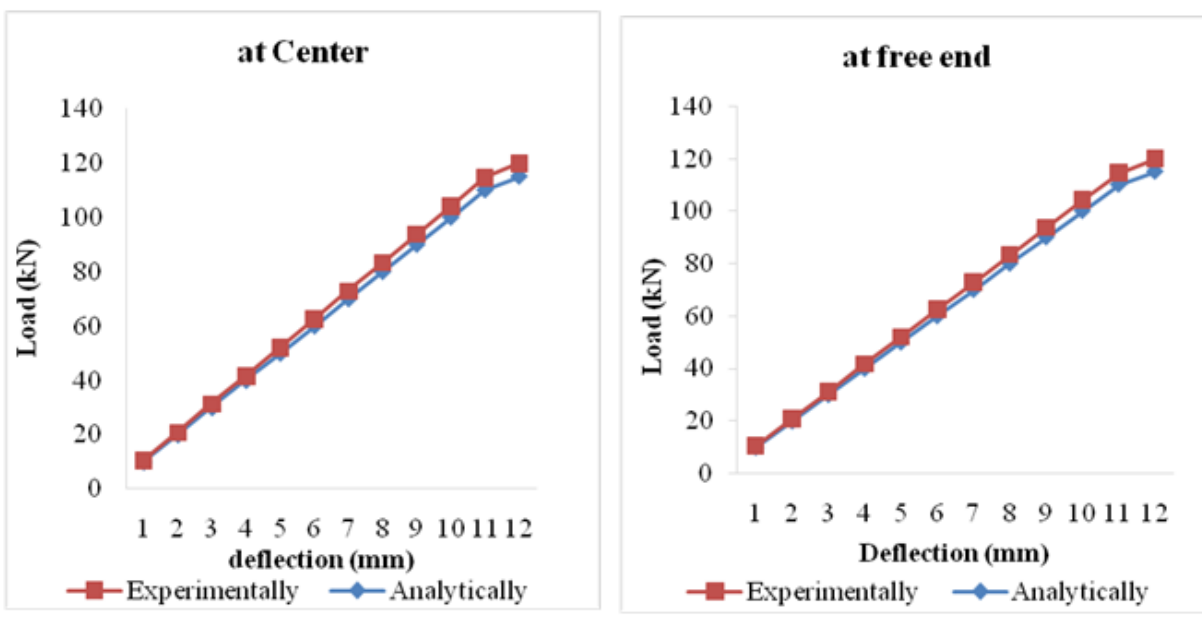

Figure 14. Load vs deflection curve in castellated cantilever beam with circular opening

\subsection{Testing on castellated fixed beams}

Table 2 shows numerical values of deflection in castellated fixed beams subjected to central point load. Deflection is measured at two locations i.e. center and $275 \mathrm{~mm}$ from fixed end. In this study also comparison of castellated beams is made with normal beam of same dimensions ( $h=125 \mathrm{~mm}, L=1100$ $\mathrm{mm})$. From Table 2 it is observed that minimum deflection is observed in castellated beams $(1.47 \mathrm{~mm})$ with hexagonal opening whereas maximum deflection is observed in normal beam $(4.40 \mathrm{~mm})$ without opening. Maximum deflections in castellated beams with square and circular openings are 2.81 $\mathrm{mm}$ and $1.82 \mathrm{~mm}$ respectively. Figure 15 shows bending and buckling behaviour of normal fixed beam without opening subjected to central point load. Variation of deflection with respect to load in fixed normal beam is shown in Figure 16. Figures 17-19 show bending and torsional buckling of castellated beams with hexagonal, square and circular openings whereas Figures 20-22 show variation of deflection with respect to load in castellated beams.

Table 2. Deflections in castellated fixed beams without and with web openings

\begin{tabular}{|c|c|c|c|c|c|c|c|c|}
\hline \multirow{3}{*}{$\begin{array}{c}\text { Load } \\
(\mathbf{k N})\end{array}$} & \multicolumn{9}{|c|}{ Deflection (mm) } \\
\cline { 2 - 9 } & \multicolumn{2}{|c|}{ Normal beam } & \multicolumn{2}{c|}{ Hexagonal opening } & \multicolumn{2}{c|}{ Square opening } & \multicolumn{2}{c|}{ Circular opening } \\
\hline & at $275 \mathrm{~mm}$ & at Center & at $275 \mathrm{~mm}$ & at Center & at $275 \mathrm{~mm}$ & at Center & at $275 \mathrm{~mm}$ & at Center \\
\hline 10 & 0.23 & 0.37 & 0.09 & 0.15 & 0.16 & 0.26 & 0.10 & 0.15 \\
\hline 20 & 0.46 & 0.73 & 0.19 & 0.29 & 0.30 & 0.47 & 0.19 & 0.30 \\
\hline 30 & 0.70 & 1.10 & 0.28 & 0.44 & 0.44 & 0.70 & 0.29 & 0.45 \\
\hline 40 & 0.93 & 1.47 & 0.37 & 0.59 & 0.59 & 0.94 & 0.38 & 0.61 \\
\hline 50 & 1.16 & 1.83 & 0.47 & 0.73 & 0.74 & 1.17 & 0.48 & 0.76 \\
\hline 60 & 1.39 & 2.20 & 0.56 & 0.88 & 0.89 & 1.41 & 0.57 & 0.91 \\
\hline 70 & 1.62 & 2.57 & 0.65 & 1.03 & 1.04 & 1.64 & 0.67 & 1.06 \\
\hline 80 & 1.86 & 2.93 & 0.74 & 1.18 & 1.19 & 1.87 & 0.77 & 1.21 \\
\hline 90 & 2.09 & 3.30 & 0.84 & 1.32 & 1.33 & 2.11 & 0.86 & 1.36 \\
\hline 100 & 2.32 & 3.66 & 0.93 & 1.47 & 1.48 & 2.34 & 0.96 & 1.51 \\
\hline 110 & 2.55 & 4.03 & -- & -- & 1.63 & 2.58 & 1.05 & 1.66 \\
\hline 120 & 2.78 & 4.40 & -- & -- & 1.78 & 2.81 & 1.15 & 1.82 \\
\hline
\end{tabular}
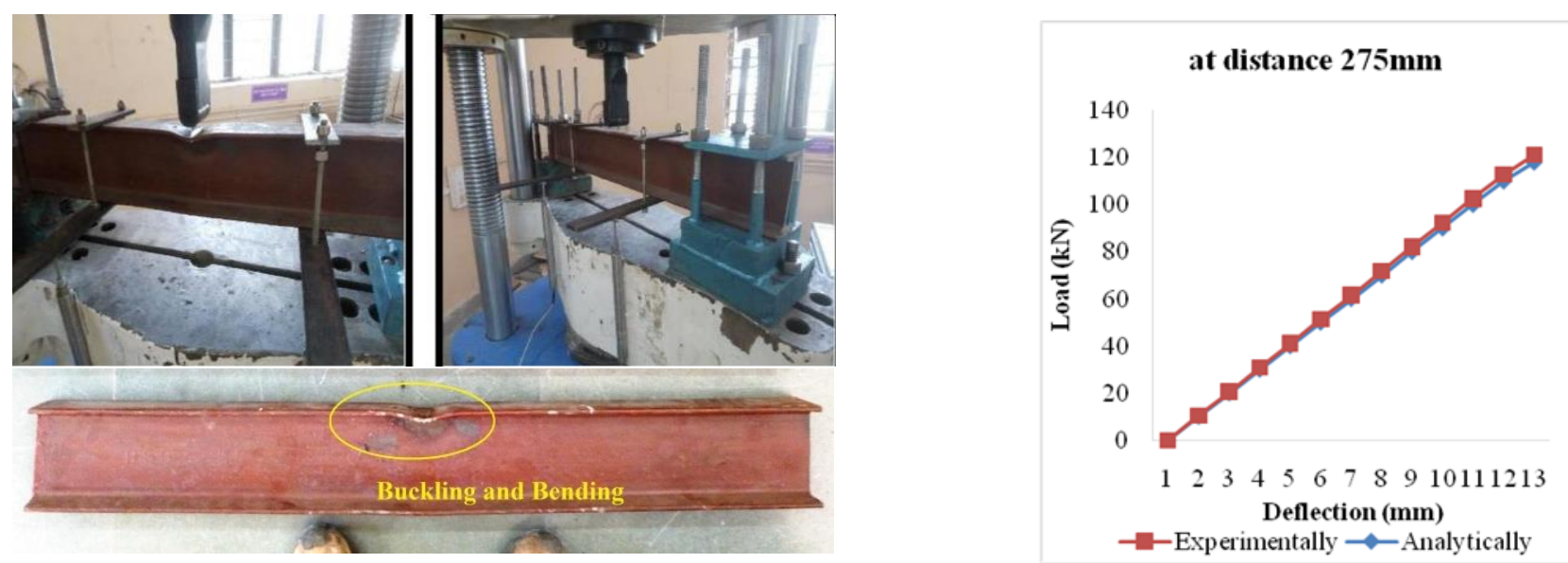

Figure 15. Bending and buckling of fixed normal beam (without opening) 


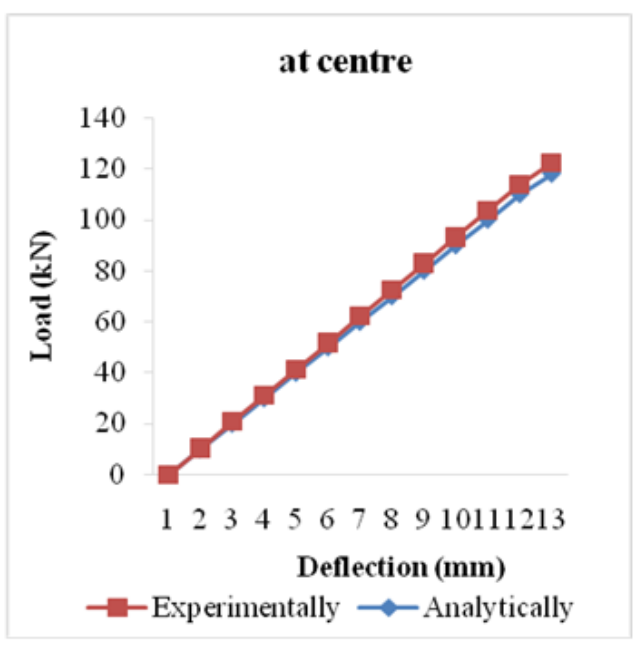

Figure 16. Load vs deflection curve in fixed normal beam

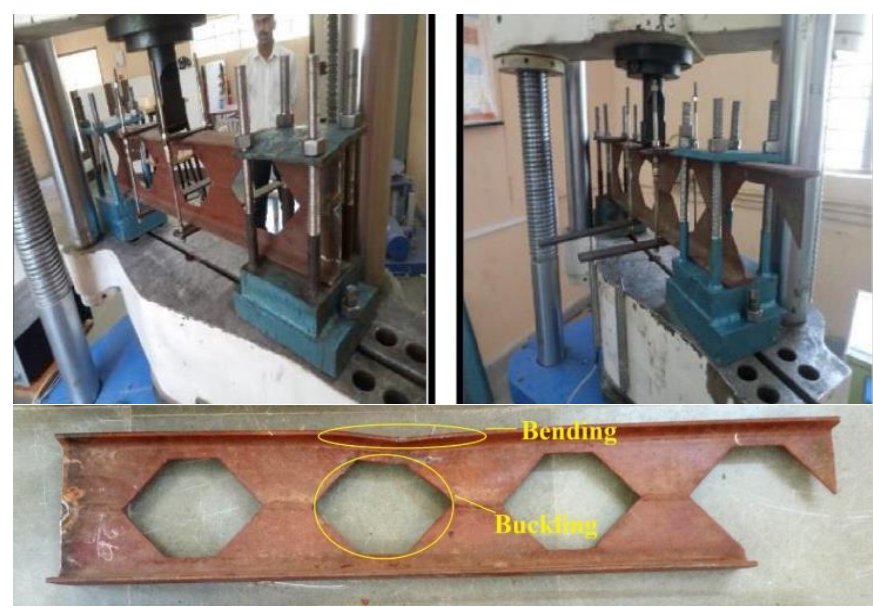

Figure 17. Lateral torsional buckling and bending in castellated fixed beam with hexagonal opening

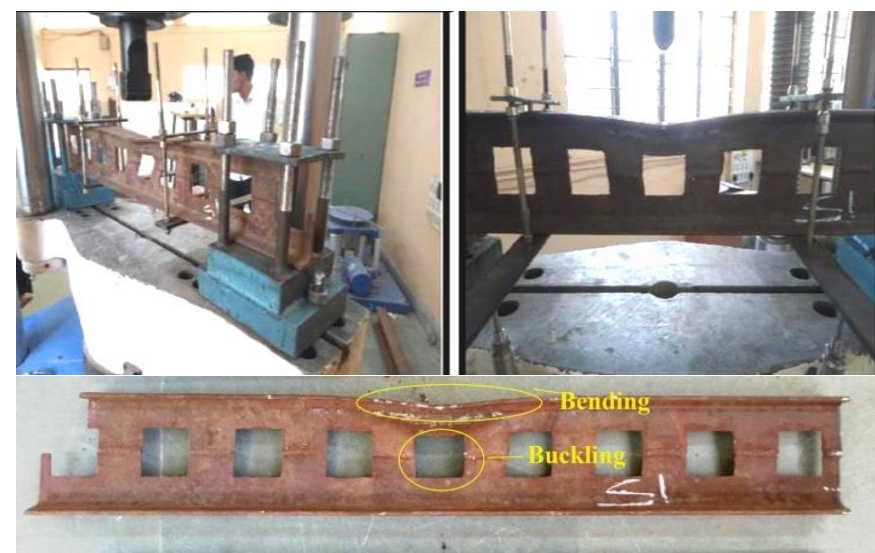

Figure 18. Lateral torsional buckling and bending in castellated fixed beam with square opening
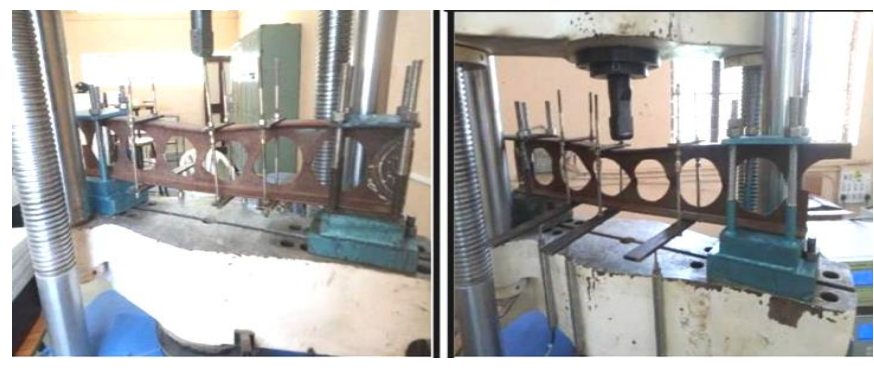

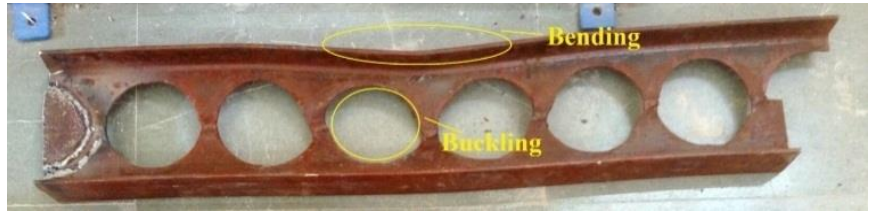

Figure 19. Lateral torsional buckling and bending in castellated fixed beam with circular opening

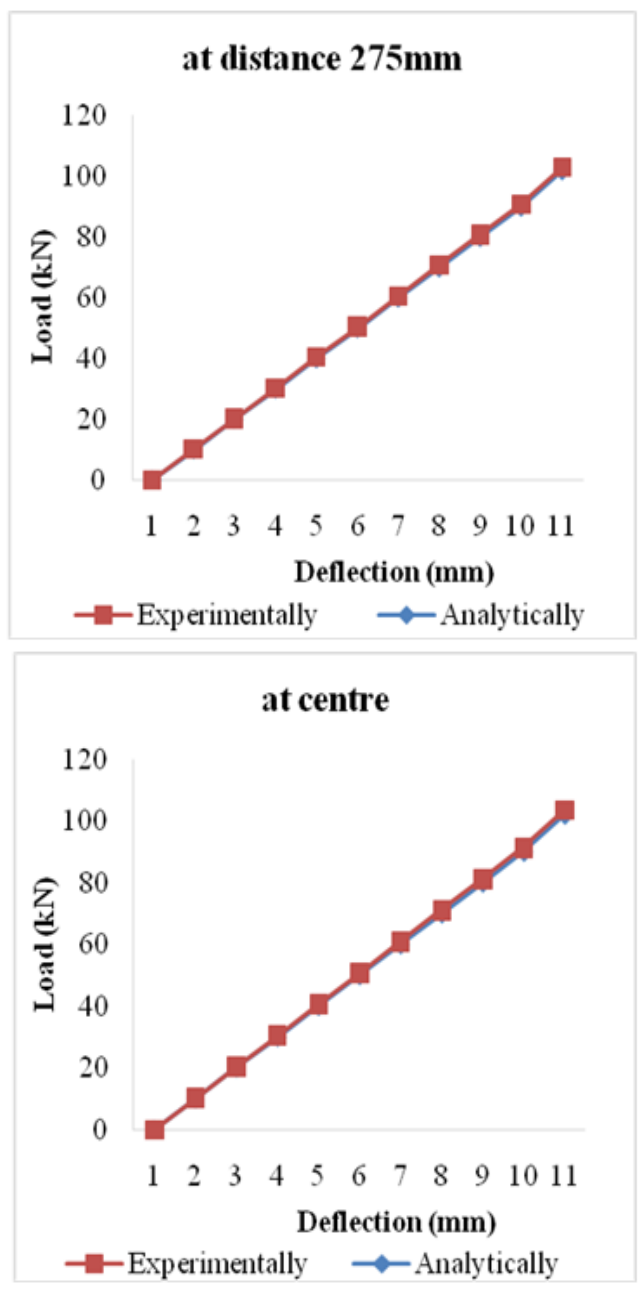

Figure 20. Load vs deflection curve in castellated fixed beam with hexagonal opening

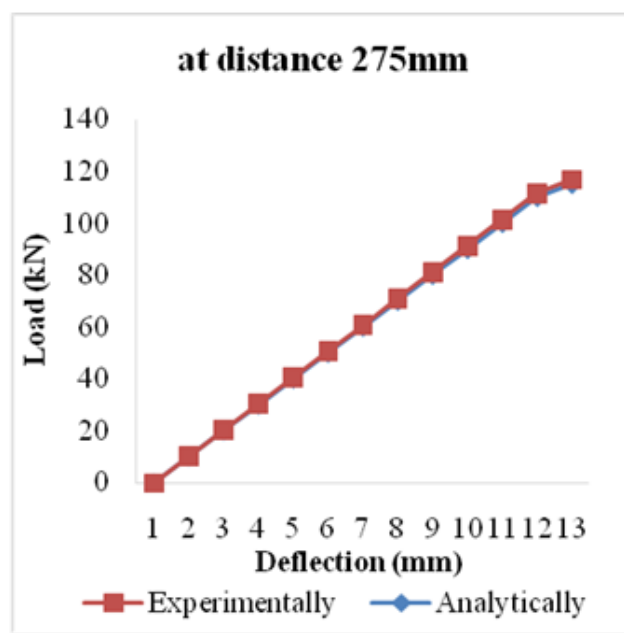




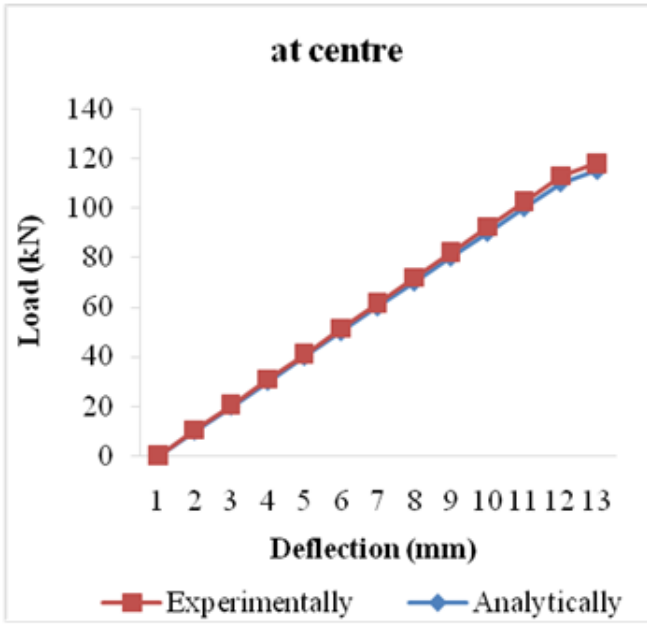

Figure 21. Load vs deflection curve in castellated fixed beam with square opening
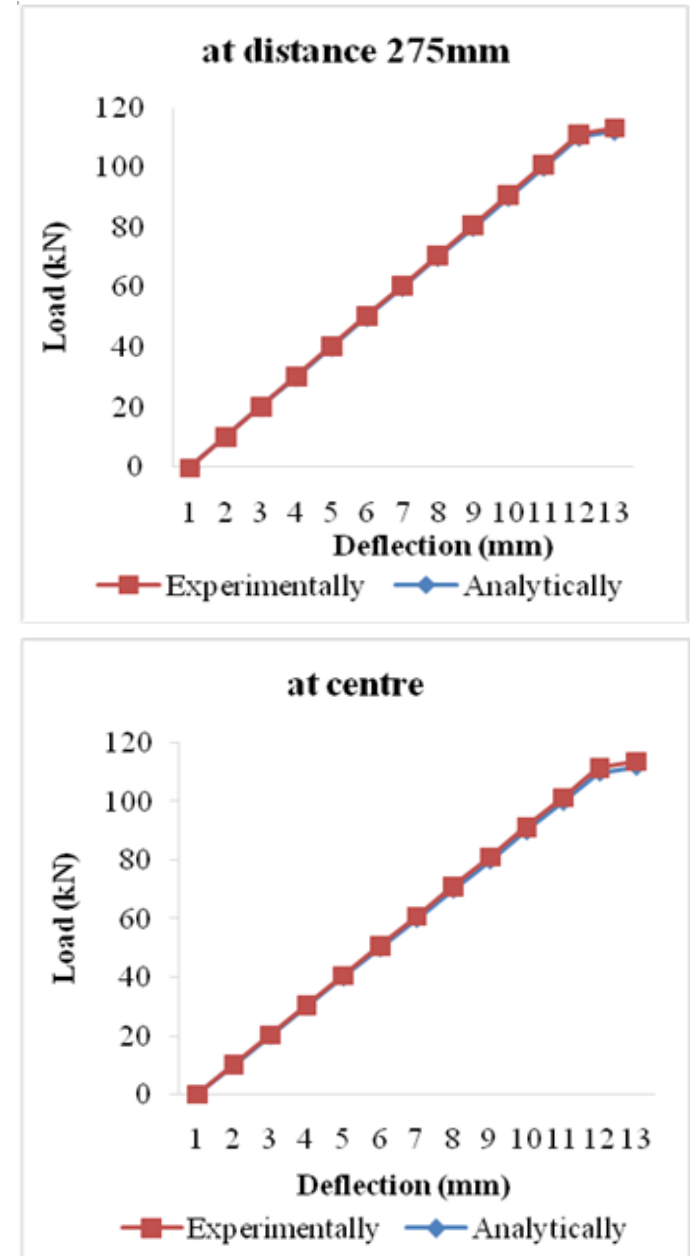

Figure 22. Load vs deflection curve in castellated fixed beam with circular opening

\section{FINITE ELEMENT ANALYSIS OF CASTELLATED BEAMS}

In this study, experimental results are validated by using finite element analysis of castellated beams using ANSYS 14.0 version. Figures 23 and 24 show deflection of castellated cantilever and fixed beams respectively.

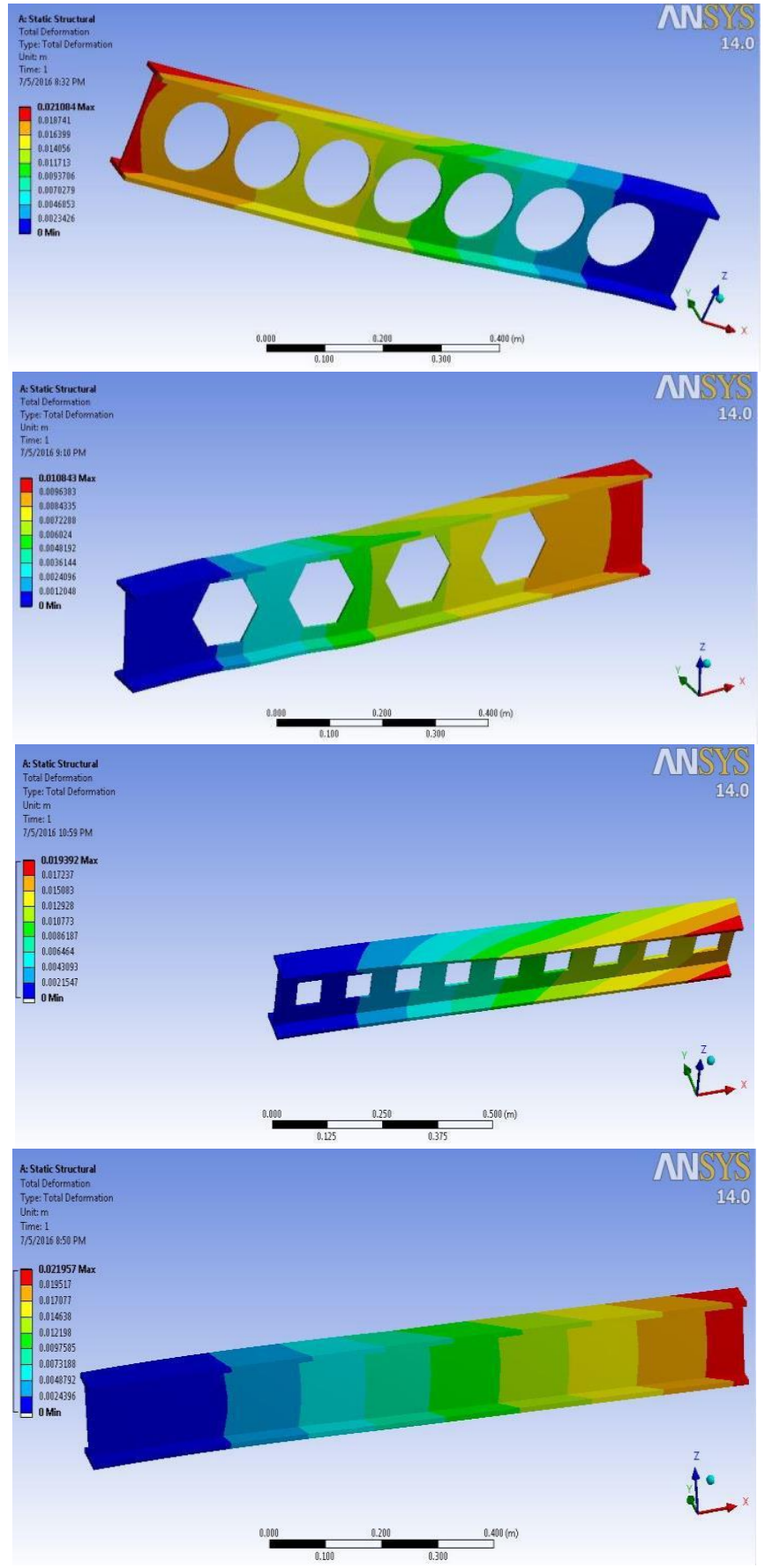

Figure 23. Finite element analysis of castellated cantilever beams using ANSYS 14.0

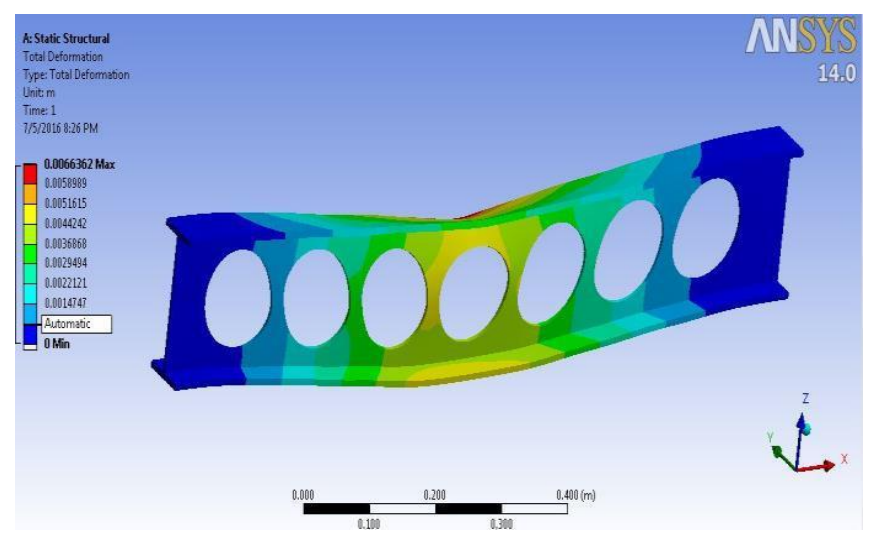



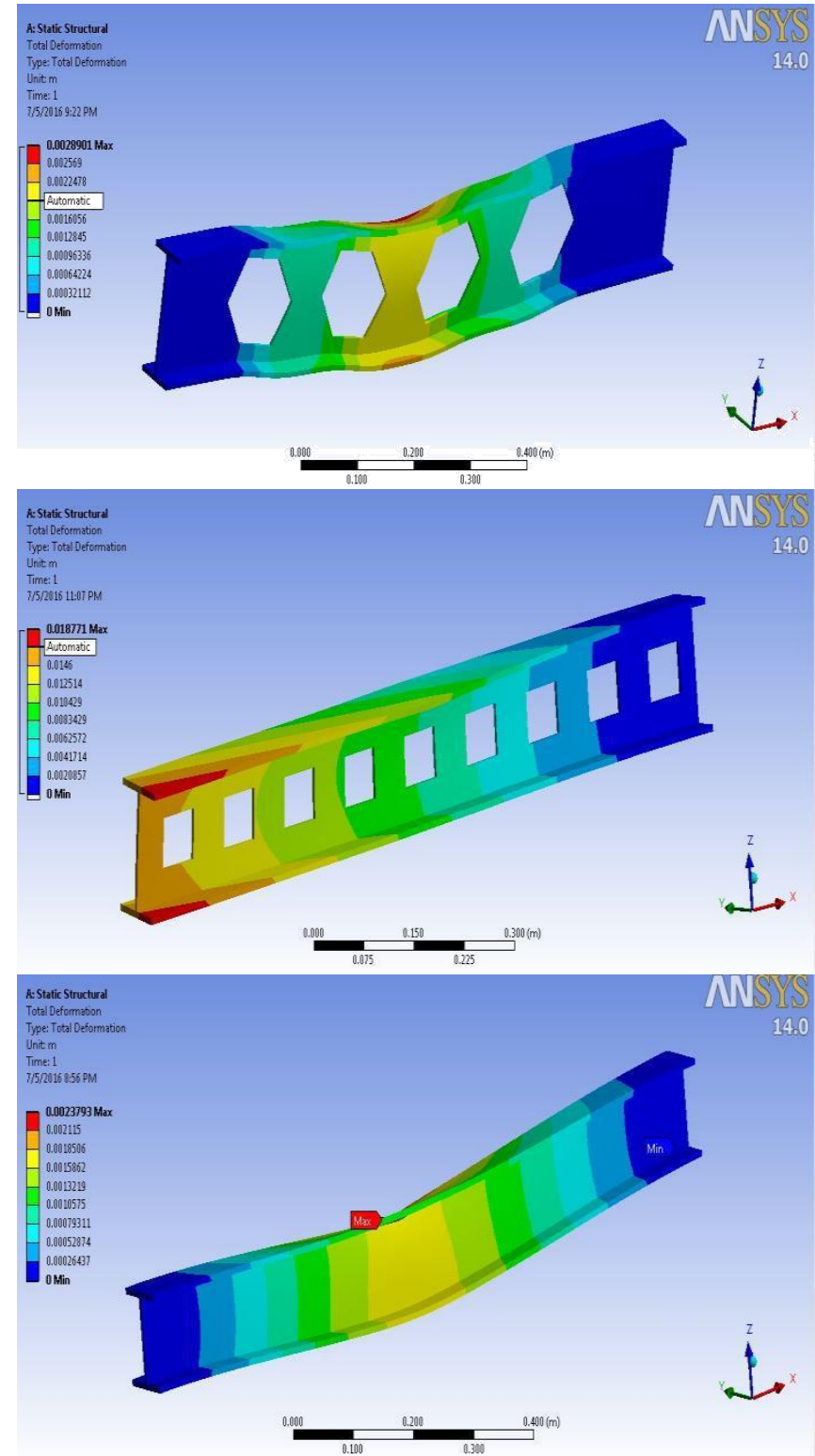

Figure 24. Finite element analysis of castellated fixed beams using ANSYS 14.0

\section{CONCLUSIONS}

In the present study, a new experimental solution is provided for bending of cantilever and fixed castellated beams with hexagonal, circular and square openings. Beams are tested under universal testing machine and subjected to central point load. Experimental results are obtained for maximum deflections and validated by using finite element analysis. By experimentally it was observed that the value of web shear deformation on the critical buckling load of castellated beam increase with the increase in cross sectional area of the Isection and depth of web opening, but decrease with the length and web thickness. It is also concluded that the effective opening shape in castellated beams is hexagonal as far as deflection is concern. But circular shape is more effective to avoid stress concentration at corners. Finally it is concluded that the present study will serve as benchmark study for cantilever and fixed castellated beams.

\section{REFERENCES}

[1] Chung, K.F., Liu, T.C.H., Ko, A.C.H. (2001). Investigation on Vierendeel mechanism in steel beams with circular web openings. Journal of Constructional Steel Research, 57(5): 467-490. https://doi.org/10.1016/S0143-974X(00)00035-3

[2] Liu, T.C.H., Chung, K.F. (2003). Steel beams with large web openings of various shapes and sizes: Finite element investigation. Journal of Constructional Steel Research, 59(9): 1159-1176. https://doi.org/10.1016/S0143974X(03)00030-0

[3] Zirakian, T., Showkati, H. (2006). Distortional buckling of castellated beams. Journal of Constructional Steel Research, 62(9): 863-871. https://doi.org/10.1016/j.jcsr.2006.01.004

[4] Zirakian, T. (2008). Lateral-distortional buckling of Ibeams and the extrapolation techniques. Journal of Constructional Steel Research, 64(1): 1-11. https://doi.org/10.1016/j.jcsr.2007.04.002

[5] Mohebkhah, A. (2004). The moment-gradient factor in lateral- torsional buckling on inelastic castellated beams. Journal of Constructional Steel Research, 60(10): 14811494. https://doi.org/10.1016/j.jcsr.2004.02.002

[6] Mohebkhah, A, Showkati, H. (2005). Bracing requirements for inelastic castellated beams. Journal of Constructional Steel Research, 61(10): 1373-1386. https://doi.org/10.1016/j.jcsr.2005.03.003

[7] Wang, A.J., Chung, K.F. (2008). Advanced finite element modeling of perforated composite beams with flexible shear connectors. Engineering Structures, 30(10): 2724-2738. https://doi.org/10.1016/j.engstruct.2008.03.001

[8] El-Sawy, K.M., Sweedan, A.M.I., Martini, M.I. (2009). Major-axis elastic buckling of axially loaded castellated steel columns. Thin Walled Structure, 47(11): 1295-1304. https://doi.org/10.1016/j.tws.2009.03.012

[9] Gholizadeh, S., Pirmoz, A., Attarnejad, R. (2011). Assessment of load carrying capacity of castellated steel beams by neural networks. Journal of Constructional Steel Research, 67(5): 770-779. https://doi.org/10.1016/j.jcsr.2011.01.001

[10] Sweedan, A.M.I. (2011). Elastic lateral stability of Ishaped cellular steel beams. Journal of Constructional Steel Research, 67(2): 151-163. https://doi.org/10.1016/j.jcsr.2010.08.009

[11] Ellobody, E. (2011). Interaction of buckling modes in castellated steel beams. Journal of Constructional Steel Research, 67(5): 814-825. https://doi.org/10.1016/j.jcsr.2010.12.012

[12] Wakchaure, M.R., Sagade, A.V. (2012). Finite element analysis of castellated steel beam. International Journal of Innovative Technology and Exploring Engineering, 2(1): 365-372.

[13] Soltani, M.R., Bouchair, A., Mimoune, M. (2012). Nonlinear FE analysis of the ultimate behavior of steel castellated beams. Journal of Constructional Steel Research, 70: 101-114. https://doi.org/10.1016/j.jcsr.2011.10.016

[14] Wong, B.V.Y., Burgess, I.W. (2013). The influence of tensile membrane action on fire-exposed composite concrete floor-steel beams with web-openings. The 9th Asia-Oceania Symposium on Fire Science and 
Technology, Procedia Engineering, 62: 710-716. https://doi.org/10.1016/j.proeng.2013.08.117

[15] Erdal, F., Dogan, E., Saka, M.P. (2011). Optimum design of cellular beams using harmony search and particle swarm optimizers. Journal of Constructional Steel Research, 67(2): 237-247. https://doi.org/10.1016/j.jcsr.2010.07.014

[16] Jamadar, M., Kumbhar, P.D. (2014). Finite element analysis of castellated beam: A review. International Journal of Innovative Research in Advanced Engineering, 1(9): 125-129.

[17] Wang, P., Ma, N., Wang, X. (2014). Numerical studies on large deflection behaviors of restrained castellated steel beams in a fire. Journal of Constructional Steel Research, 100: 136-145. https://doi.org/10.1016/j.jcsr.2014.04.026

[18] Elsawaf, S.A., Hassan, M.M. (2018). Behavior of structural sub-assemblies of steel beams with openings in fire conditions. Journal of Constructional Steel Research, 148: 627 638. https://doi.org/10.1016/j.jcsr.2018.06.023

[19] Tsavdaridis, K.D., Papadopoulos, T. (2016). A FE parametric study of RWS beam-to-column bolted connections with cellular beams. Journal of Constructional Steel Research, 116: 92-113. https://doi.org/10.1016/j.jcsr.2015.08.046

[20] Zhou, X., Li, J., He, Y., He, Z., Li, Z. (2018). Finite element analysis of thermal residual stresses in castellated beams. Journal of Constructional Steel Research, 148:

741-755. https://doi.org/10.1016/j.jcsr.2018.06.026

[21] Harte, A.M., Baylor, G. (2011). Structural evaluation of castellated timber I-joists. Engineering Structures, 33(12): 3748-3754. https://doi.org/10.1016/j.engstruct.2011.08.011

[22] Baylor, G., Harte, A.M. (2013). Finite element modeling of castellated timber I-joists. Construction and Building Materials, 47: 680-688. https://doi.org/10.1016/j.conbuildmat.2013.05.076

[23] Gandomi, A.H., Tabatabaei, S.M., Moradian, M.H., Radfar, A., Alavi, A.H. (2011). A new prediction model for the load capacity of castellated steel beams. Journal of Constructional Steel Research, 67(7): 1096-1105. https://doi.org/10.1016/j.jcsr.2011.01.014

[24] Erdal, F., Saka, M.P. (2013). Ultimate load carrying capacity of optimally designed steel cellular beams. Journal of Constructional Steel Research, 80: 355-368. https://doi.org/10.1016/j.jcsr.2012.10.007

[25] Durif, S., Bouchair, A. (2012). Behavior of cellular beams with sinusoidal openings. Procedia Eng., 40: 108113. https://doi.org/10.1016/j.proeng.2012.07.064

[26] Tsavdaridis, K.D., D'Mello, C. (2012). Optimization of novel elliptically-based web opening shapes of perforated steel beams. Journal of Constructional Steel Research, 76: 39-53. https://doi.org/10.1016/j.jcsr.2012.03.026

[27] Showkati, H., Ghazijahani, T.G., Noori, A., Zirakian, T. (2012). Experiments on elastically braced castellated beams. Journal of Constructional Steel Research, 77: 163-172. https://doi.org/10.1016/j.jcsr.2012.05.008

[28] Durif, S., Bouchair, A., Vassart, O. (2013). Experimental tests and numerical modeling of cellular beams with sinusoidal openings. Journal of Constructional Steel Research, 82:

$72-87$. https://doi.org/10.1016/j.jcsr.2012.12.010
[29] Zainal Abidin, A.R., Izzuddin, BA. (2013). Mesh less local buckling analysis of steel beams with irregular web openings. Engineering Structures, 50: 197-206. https://doi.org/10.1016/j.engstruct.2012.10.006

[30] Yuan, W., Kim, B., Li, L. (2014). Buckling of axially loaded castellated steel columns. Journal of Constructional Steel Research, 92: 40-45. https://doi.org/10.1016/j.jcsr.2013.10.013

[31] Sonck, D., Impe, R.V., Belis, J. (2014). Experimental investigation of residual stresses in steel cellular and castellated members. Construction and Building Materials, 54: 512-519. https://doi.org/10.1016/j.conbuildmat.2013.12.045

[32] Sorkhabi, R.V., Naseri, A., Naseri, M. (2014). Optimization of the castellated beams by particle swarm algorithms method. APCBEE Procedia, 9: 381-387. https://doi.org/10.1016/j.apcbee.2014.01.067

[33] Wang, P., Ma, Q., Wang, X. (2014). Investigation on Vierendeel mechanism failure of castellated steel beams with fillet corner web openings. Engineering Structures, 74: 44-51. https://doi.org/10.1016/j.engstruct.2014.05.008

[34] Wang, P., Wang, X., Ma, N. (2014). Vertical shear buckling capacity of web-posts in castellated steel beams with fillet corner hexagonal web openings. Engineering Structures, $\quad$ 75: 315-326. https://doi.org/10.1016/j.engstruct.2014.06.019

[35] Ellobody, E., Young, B. (2015). Nonlinear analysis of composite castellated beams with profiled steel sheeting exposed to different fire conditions. Journal of Constructional Steel Research, 113: 247-260. https://doi.org/10.1016/j.jcsr.2015.02.012

[36] Tsavdaridis, K.D., Kingman, V.V., Toropov. (2015). Application of structural topology optimisation to perforated steel beams. Computers \& Structures, 158: 108-123. https://doi.org/10.1016/j.compstruc.2015.05.004

[37] Sonck, D., Belis, J. (2015). Lateral-torsional buckling resistance of cellular beams. Journal of Constructional Steel Research, 105: 119-128. https://doi.org/10.1016/j.jcsr.2014.11.003

[38] Sonck, D., Belis, J. (2016). Weak-axis flexural buckling of cellular and castellated columns. Journal of Constructional Steel Research, 124: 91-100. https://doi.org/10.1016/j.jcsr.2016.05.002

[39] Wang, P., Guo, K., Liu, M., Zhang, L. (2016). Shear buckling strengths of web-posts in a castellated steel beam with hexagonal web openings. Journal of Constructional Steel Research, 121: 173-184. https://doi.org/10.1016/j.jcsr.2016.02.012

[40] Najafi, M., Wang, Y.C. (2017). Behavior and design of steel members with web openings under combined bending, shear and compression. Journal of Constructional Steel Research, 128: 579-600. https://doi.org/10.1016/j.jcsr.2016.09.011

[41] Grilo, L.F., Fakury, R.H., Silva, A.L.R.C., Verissimo, G.S. (2018). Design procedure for the web-post buckling of steel cellular beams. Journal of Constructional Steel Research, 148 : 525-541. https://doi.org/10.1016/j.jcsr.2018.06.020

[42] Zaher, O.F., Yossef, N.M., El-Boghdadi, M.H., Dabaon, M.A. (2018). Structural behavior of arched steel beams with cellular openings. Journal of Constructional Steel Research, 148: 756-767. 